\title{
URGENSI PENGATURAN PENGEMBANGAN ENERGI TERBARUKAN SEBAGAI WUJUD MENDUKUNG KETAHANAN ENERGI NASIONAL
}

\author{
FAISAL \\ Sekolah Tinggi Ilmu Hukum Putri Maharaja Payakumbuh \\ faisal.buchari61@gmail.com
}

\begin{abstract}
Energy sovereignty in Indonesia is experiencing problems with a decline in national energy security. Indonesia's energy system is currently facing serious challenges. The imbalance in the condition of energy supplies with national energy needs, especially the oil and gas sector and efforts to fulfill national energy needs in a sustainable manner are the main problems of this nation in the energy sector. It is absolutely necessary to have strategic efforts in the field of creating new and renewable energy. Although the government has issued various policies to catch up, but to realize national energy security, it is necessary to urgently regulate the development of renewable energy as a form of supporting national energy security. As for the formulation of the problems raised in this study are: support national energy security in Indonesia? 2) what is the urgency of regulating the development of renewable energy as a form of supporting national energy security? This research will use normative juridical research and supported by empirical juridical research so that it will be able to see the conditions of developing renewable energy as a form of supporting national energy security in Indonesia. To realize this, it is necessary to urgently regulate the development of renewable energy as a form of supporting national energy security
\end{abstract}

Keywords: Energy, Renewable, Resilience, National Energy.

Abstrak: Kedaulatan energi di Indonesia tengah mengalami masalah dengan adanya penurunan ketahanan energi nasional. Sistem energi Indonesia saat ini sedang menghadapi tantangan serius. Ketimpangan kondisi persediaan energi dengan kebutuhan energi nasional, terutama sektor migas dan upaya pemenuhan kebutuhan energi nasional secara berkelanjutan merupakan permasalahan utama bangsa ini pada bidang energi. Mutlak diperlukan upaya- upaya strategis dalam bidang penciptaan energi baru dan terbarukan. Meskipun pemerintah telah mengeluarkan berbagai kebijakan untuk mengejar ketertinggalan, namun untuk mewujudkan ketahanan energi nasional, maka diperlukan urgensi pengaturan pengembangan energi terbarukan sebagai wujud mendukung ketahanan energi nasional.Adapun rumusan masalah yang diangkat dalam penelitian ini adalah: 1) bagaimana kondisi pengembangan energi terbarukan sebagai wujud mendukung ketahanan energi nasional di Indonesia? 2) bagaimana urgensi pengaturan pengembangan energi terbarukan sebagai wujud mendukung ketahanan energi nasional? Penelitian ini akan menggunakan penelitian yuridis normatif dan didukung penelitian yuridis empiris seingga akan bisa melihat kondisi pengembangan energi terbarukan sebagai wujud mendukung ketahanan energi nasional di Indonesia. Untuk mewujudkan hal tersebut maka perlu urgensi pengaturan pengembangan energi terbarukan sebagai wujud mendukung ketahanan energi nasional Kata kunci: Energi, Terbarukan, Ketahanan, Energi Nasional. 


\section{A. Pendahuluan}

Sumber daya alam energi memiliki peranan yang sangat besar bagi suatu negara, baik dalam segi ekonomi, sosial maupun pembangunan nasional. Indonesia sendiri, mengingat keadaan fisik alamnya, sangatlah kaya akan berbagai sumber daya alam dan potensi energi yang melimpah baik dalam bentuk sumber daya energi tak terbarukan maupun sumber daya energi terbarukan. Oleh karena itu, dapat disimpulkan bahwa Indonesia, sejatinya, memiliki kemampuan yang besar untuk menghasilkan energiguna menyokong kesejahteraan penduduknya (Iwan J. Azis, 2010).

Pada praktiknya, saat ini, ketersediaan energi di Indonesia tidak lagi dapat menunjang kebutuhan energi yang terus meningkat tersebut. Secara garis besar, fenomena ini terjadi atas beberapa faktor, diantaranya produksi energi di Indonesia yang menurun dari tahun ke tahun, serta terjadinya penipisan sumber daya cadangan yang dimiliki Indonesia. Ditambah lagi, terlepas dari ketersediaan sumber daya terbarukan, hingga saat ini, Indonesia masih menitik beratkan sumber daya energi tak terbarukan yang berasal dari fosil, seperti: minyak bumi, batu bara dan gas alam, sebagai bahan bakar energi (Farah Nabila, 2015). Bukan tidak mungkin jika ketergantungan ini akan berakibat kepada kelangkaan sumber energi.

Pemakaian energi di Indonesia masih didominasi penggunaan energi berbasis fosil terutama bahan bakar minyak bumi dan batu bara. Apabila dalam waktu dekat tidak ditemukan sumber-sumber energi baru yang signifikan pada tahun 2046 mendatang dikhawatirkan Indonesia akan mengalami defisit energi. Saat ini, sudah tidak boleh lagi bergantung pada ekonomi berbasis fosil karena cadangan fosil di berbagai negara sudah menurun, termasuk Indonesia. Penggunaan energi baru dan terbarukan, harus menjadi perhatian utama pemerintah Indonesia. Penggunaan energi baru dan terbarukan ini tidak hanya sebagai upaya untuk mengurangi pemakaian energi fosil (Satya Widya Yudha, 2017).

Indonesia pada saat ini juga sedang berkembang menjadi pasar energi yang besar di Asia. Dengan populasi dan pertumbuhan ekonomi yang tinggi, permintaan energi di dalam negeri yang terus meningkat serta penurunan produksi minyak bumi di dalam negeri telah menggiring Indonesia menjadi pengimpor energi dengan volume yang terus membesar (Metta Dharmasaputra, 2014). Seiring dengan pertumbuhan konsumsi energinya, Indonesia menghadapi berbagai tantangan/permasalahan ketahanan energi.

Mempertahankan keamanan pasokan energi dalam jangka panjang merupakan tugas berat di tengah kemampuan pasokan minyak bumi dalam memenuhi kebutuhan energi nasional yang kian terbatas. Hal ini tentu tidak terlepas dari begitu cepatnya transisi energi yang dialami oleh Indonesia.

Energi memainkan peran yang sangat penting dalam semua sektor kehidupan (industri, transportasi, rumah tangga, komersial, dan lain-lain). Persoalan yang sering muncul dalam konsumsi energi pada sektor rumah tangga adalah adanya disparitas (perbedaan) dalam konsumsi energi dan aksesibilitas terhadap sumber energi. Karakteristik konsumsi energi pada sektor rumah tangga di Indonesia adalah adanya dominasi dalam konsumsi energi non komersial, dominasi kelompok rumah tangga kaya dalam konsumsi energi komersial, rendahnya porsi rata-rata pengeluaran rumah tangga untuk energi dibandingkan rata-rata pengeluaran secara umum, serta cukup signifikannya rata-rata pertumbuhan per tahun dari konsumsi energi komersial pada sektor rumah tangga (Fery Triatmojo, 2013).

Terwujudnya sistem energi yang berkelanjutan akan mampu memberikan ketahanan energi nasional yang merupakan salah satu pondasi ketahanan nasional. Ketahanan energi nasional tersebut mencakup pengertian kemampuan Indonesia untuk E-ISSN: 2657-0300 Lembaga Penelitian dan Penerbitan Hasil Penelitian Ensiklopedia 19 
memenuhi kebutuhan energinya sendiri sehingga memiliki derajat kebebasan setinggi mungkin terhadap pengaruh asing terhadap sektor yang merupakan urat nadi kedaulatan tersebut.

Selain itu dengan adanya perubahan Undang-Undang tentang Pemerintahan Daerah dari Undang-Undang Nomor 32 Tahun 2004 bergeser menjadi UndangUndang Nomor 23 tahun 2014 tentang Pemerintah Daerah, telah menimbulkan kewenangan pengelolaan sejumlah sektor dari daerah ke pusat. ia mencontohkan pada sektor pertambangan, kehutanan, dan pendidikan terjadi pengalihan kewenangan dari daerah ke provinsi. Daerah berhak menetapkan kebijakan daerah dalam menyelenggarakan urusan pemerintahan yang menjadi kewenangan daerah pada pasal 17 ayat 1.

Akhirnya, nampak diperlukan kajian analisis akademik secara mendalam untuk memahami berbagai permasalahan-permasalahan kebijakan energi nasional yang terbarukan tersebut untuk mendukung ketahanan energi nasional. Berangkat dari berbagai paparan-paparan di atas, maka kajian sederhana yang hendak dibahas dari tulisan ini akan membahas mengenai pengembangan energi terbarukan sebagai wujud mendukung ketahanan energi nasional.

\section{B. Metode Penelitian}

Sebagaimana diketahui kata metode berasal dari kata Yunani "methods" atau dari kata latin "methodus" yang berarti upaya untuk mencari pengetahuan dan memeriksa secara rasional (atau meneliti) dan cara melakukan kegiatan penelitian (C.F.G Sunaryati Hartono, 2006). Metode penelitian pada dasarnya tidak lebih dari tiga langkah sederhana, yaitu dengan melakukan pengamatan dengan cermat, menyusun penjelasan berdasarkan temuan-temuan yang masih belum dipahami, kemudian menguji penjelasan tersebut (Stephan S Carey, 2015). Menemukan berarti berusaha mendapatkan sesuatu untuk mengisi kekosongan atau kekurangan. Mengembangkan berarti memperluas dan menggali dalam apa yang sudah ada, sedangkan menguji kebenaran dilakukan jika apa yang sudah ada masih atau menjadi diragukan kebenarannya (Beni Ahmad Saebani, 2009). Dalam penelitian hukum harus dilakukan dengan aktivitas-aktivitas untuk mengungkap kebenaran hukum yang dilakukan secara terencana dan metodologis. Penelitian ini merupakan penelitian deskriptif yang menggambarkan peran DPD RI terhadap pembangunan daerah perbatasan dan tertinggal dalam era otonomi daerah. Pendekatan yang digunakan dalam penelitian ini, adalah pendekatan yuridis normatif yang didukung pendekatan yuridis empiris, digunakan untuk mengetahui peran DPD RI terhadap pembangunan daerah perbatasan dan tertinggal dalam era otonomi daerah.

\section{Hasil dan Pembahasan}

Energi merupakan sebuah unsur yang diperoleh dari sumber daya alam yang berfungsi untuk memenuhi segala kebutuhan makhluk hidup terutama bagi manusia dalam menjalani aktivitasnya. Penggunaan energi tersebut dimaksudkan sebagai bentuk upaya manusia untuk dapat mempertahankan keberadaannya dan mampu meningkatkan kesejahteraan dan kemakmuran hidupnya. Penggunaan terhadap energi tersebut sering dimanfaatkan oleh manusia sebagai sumber untuk penyediaan tenaga listrik. Upaya tersebut sejalan dengan apa yang tercantum didalam Konstitusi Negara Republik Indonesia, yaitu pada Pasal 33 Ayat (3) UUD 1945 yang menyatakan bahwa 
"Bumi dan air dan kekayaan alam yang terkandung di dalamnya dikuasai negara dan dipergunakan untuk sebesar-besarnya kemakmuran rakyat".

Pemanfaatan terhadap energi oleh manusia lebih didominasi kepada penggunaan energi fosil yang jumlah Ketersediannya sangat terbatas. Selain itu, Pemanfaatan atas energi tersebut sering digunakan secara terus-menerus sehingga dapat menyebabkan kelangkaan atau bahkan menyebabkan habisnya suatu energi. Oleh karena itu Energi Baru dan Terbarukan muncul sebagai suatu Inovasi dan alternatif untuk mengatasi permasalahan tersebut sebagai upaya untuk mencegah kelangkaan energi yang nantinya akan berdampak pada terganggunya stabilitas kehidupan makhluk hidup.

Menurut definisi International Energy Agency (IEA), Energi Baru dan Terbarukan adalah energi yang berasal dari proses alam yang diisi ulang secara terus menerus dan secara berkelanjutan dapat terus diproduksi tanpa harus menunggu waktu jutaan tahun layaknya energi berbasis fosil. EBT merupakan energi alternatif yang dapat dimanfaatkan oleh manusia di zaman modern ini sebagai pengganti dari energi fosil yang sifatnya tidak dapat diperbaharui dan tak terbarukan. Pemahaman EBT menurut Undang-Undang No 30 Tahun 2007 dapat diklasifikasikan menjadi 2 (dua) bagian, yaitu "Energi baru" yang berasal dari sumber energi baru yaitu jenis-jenis energi yang pada saat ini belum dipergunakan secara massal oleh manusia dan masih dalam tahap pengembangan teknologi. Sedangkan, "Energi terbarukan" merupakan energi yang berasal dari sumber energi terbarukan yang ketersediaan sumbernya bisa digunakan kembali setelah sumber itu digunakan atau dihabiskan. Selain itu, Pemanfaatan energi baru terbarukan dinilai lebih ramah lingkungan karena mampu mengurangi pencemaran lingkungan dan kerusakan lingkungan jika dibandingkan dengan energi tak terbarukan karena EBT cukup cepat untuk dapat dipulihkan kembali secara alami. Artinya, EBT yang dihasilkan dari sumber daya energi yang secara alami tidak akan habis jumlahnya dan dapat bersifat berkelanjutan apabila dikelola dengan baik. Oleh karena itu, Energi Baru dan terbarukan dapat disebut juga sebagai energi yang berkelanjutan (sustainable energy).

Potensi yang dimiliki oleh Energi Baru dan Terbarukan ini cukup banyak jenisnya dan sangat bermanfaat sekali bagi manusia dalam menunjang kebutuhan hidupnya terutama dalam penyediaan tenaga listrik sebagai sumber pengganti dari Energi Fosil yang tidak dapat diperbaharui dan jumlahnya sangat terbatas. Beberapa sumber Energi Baru dan Terbarukan misalnya Biofuel, biomasa, panas bumi, Pembangkit Listrik Tenaga Panas Bumi (PLTP), angin, energi matahari, pasang surut dan gelombang laut.

Penerapan Energi Baru Terbarukan di Indonesia tentunya harus dilaksanakan sesuai dengan Asas Perlindungan dan Pengelolaan Lingkungan Hidup yang tercantum dalam UU No 32 Tahun 2009 Tentang Perlindungan dan Pengelolaan Lingkungan Hidup. Asas-asas PPLH tersebu terdiri dari: Asas kelestarian dan keberlanjutan. Asas ini menjelaskan bahwa setiap orang memikul kewajiban dan tanggung jawab terhadap generasi mendatang dan terhadap sesamanya dalam satu generasi dengan melakukan upaya pelestarian daya dukung ekosistem dan memperbaiki kualitas lingkungan hidup. Oleh karena itu, EBT hadir untuk menyediakan Energi yang lebih ramah lingkungan dan dapat digunakan secara terus menerus sehingga keberadaan EBT masih akan terjaga hingga masa yang akan datang.

Asas keanekaragaman hayati, asas ini menjelaskan Bahwa perlindungan dan pengelolaan lingkungan hidup harus memperhatikan upaya terpadu untuk mempertahankan keberadaan, keragaman, dan keberlanjutan sumber daya alam hayati yang terdiri atas sumber daya alam nabati dan sumber daya alam hewani yang bersama 
dengan unsur nonhayati di sekitarnya secara keseluruhan membentuk ekosistem. Hal inipun perlu diperhatikan dalam Penerapan Energi Baru Terbarukan, dimana penggunaan EBT merupakan salah satu alternative dari penggunaan Energi tak terbarukan dan tidak dapat diperbaharui yang dapat mengancam dan mengurangi eksistensi keanekaragaman hayati.

Asas Ekorigion, asas ini menjelaskan Bahwa dalam perlindungan dan pengelolaan lingkungan hidup harus memperhatikan karakteristik sumber daya alam, ekosistem, kondisi geografis, budaya masyarakat setempat, dan kearifan local yang ada. Artinya keberadaan EBT dapat menjadi suatu langkah bagi Pemerintah beserta masyarakat untuk dapat memanfaatkan setiap Energi yang tersedia di Indonesia yang sifatnya dapat diperbaharui kembali.

Asas Kemanfaatan, asas ini menjelaskan Bahwa segala usaha dan/atau kegiatan pembangunan yang dilaksanakan disesuaikan dengan potensi sumber daya alam dan lingkungan hidup untuk peningkatan kesejahteraan masyarakat dan harkat manusia selaras dengan lingkungannya. Hal tersebut dapat mempertegas hadirnya EBT yang mampu memberikan berbagai manfaat yang besar dalam Penggunaan Energi bagi Kehidupan masyarakat yang makmur dan sejahtera.

Asas Keadilan, asas ini menjelaskan Bahwa perlindungan dan pengelolaan lingkungan hidup harus mencerminkan keadilan secara proporsional bagi setiap warga negara, baik lintas daerah, lintas generasi, maupun lintas gender. Artinya, aalam melaksanakan kebijakan pengelolaan dan perlindungan lingkungan hidup harus memperhatikan keberlanjutan dan regenerasi yang baik bagi setiap masyarakat di masa kini dan masa yang akan datang. Oleh karenanya, Energi Baru Terbarukan dapat menjadi solusi untuk melakanakan kebijakan tersebut.

Asas Tanggung jawab Negara, asas ini menjelaskan bahwa Pemanfaatan EBT merupakan upaya pemerintah dalam melaksanaan pengelolaan dan perlindungan lingkungan hidup yang baik dan dapat dilaksanakan dengan cara: 1) negara menjamin pemanfaatan sumber daya alam akan memberikan manfaat yang sebesar-besarnya bagi kesejahteraan dan mutu hidup rakyat, baik generasi masa kini maupun generasi masa depan; 2) negara menjamin hak warga negara atas lingkungan hidup yang baik dan sehat; dan 3) negara mencegah dilakukannya kegiatan pemanfaatan sumber daya alam yang menimbulkan pencemaran dan/atau kerusakan lingkungan hidup.

Dalam Proses Pelaksanaannya, Pelaksanaan EBT di Indonesia hingga saat ini mulai sedikit demi sedikit diterapkan dan masih tetap terus digalakan oleh Negara sebagai bentuk upaya Pemerintah menyediakan energi untuk kehidupan masyarakat seperti ketersediaan tenaga listrik dan bahan bakar. Hal ini didasarkan kepada semakin meningkatnya kesadaran umat manusia untuk mengelola dan menjaga kelestarian lingkungan dengan baik sehingga diperlukan energi yang bersifat ramah lingkungan. Kesadaran masyarakat dan pemerintah akan hal tersebut ditandai dengan kondisi global yang sedang populer dimana pemanfaatan energi sudah mengarah kepada energi yang berasal dari Energi Baru Terbarukan. Selain itu, EBT dapat berperan dalam menjawab beberapa masalah lingkungan yang ada. Contohnya mengenai kondisi energi nasional saat ini, Dimana 90\% energi yang dimanfaatkan berasal dari energi fosil yang semakin berkurang keberadaannya dan merupakan faktor penting terjadinya perubahan iklim.

Pemanfaatan EBT ini sangat diperlukan oleh masyarakat dalam penyediaan tenaga listrik untuk kebutuhan hidup sehari-hari. Jika melihat kepada Jumlah penduduk 
Indonesia saat ini, dimana populasinya sangat besar, yaitu sekitar lebih dari 250 juta jiwa dengan Pertumbuhan kebutuhan energi listrik sekitar $8 \%$ per tahun, yang kemudian berakibat kepada terjadinya peningkatan energi listrik yang signifikan, yaitu sekitar 7000 MW per tahun. Maka dari itu, diperlukanlah keamanan pasokan bagi ketersediaan energi, khususnya energi listrik.

Selain itu, Disamping Pemanfaatan EBT di Indonesia yang cenderung mengarah kepada hal-hal positif, ternyata EBT pun masih terdapat sedikit kendala dalam pelaksanaannya. Diantaranya yaitu mengenai Pemanfaatan EBT yang dinilai masih membutuhkan biaya pengadaan dan operasional yang cukup tinggi dan jauh melampaui energi konvensional dan energi fosil lainnya (minyak dan batu bara). Selain itu, EBT memiliki nilai investasi yang tinggi sehingga memberikan dampak serius pada kenaikan tarif listrik. Akan tetapi, Permasalahan EBT tersebut dinilai dapat cukup mudah untuk diselesaikan karena akan adanya kerjasama Pemerintah dengan pihak swasta untuk mengoperasionalkan Pemanfaatan EBT di Indonesia.

Gagasan Mengenai Pemanfaatan EBT di Indonesia sebenarnya telah digagas beberapa tahun kebelakang yang ditandai dengan terbitnya beberapa UU yang mengatur EBT tersebut. Akan tetapi, perhatian dan kebutuhan masyarakat dan pemerintah terhadap EBT ini tidak terbatas pada beberapa waktu kebelakang, tetapi akan berjalan secara berkelanjutan. Hal ini ditandai dengan diterbitkannya Permen ESDM No 4 Tahun 2020 atas Perubahan Permen ESDM No 50 Tahun 2017, dimana UU tersebut mengalami pembaharuan dan peningkatan berdasarkan kebutuhan yang dialami saat ini. Sehingga pada dasarnya, kebijakan mengenai EBT akan terus berjalan hingga masa yang akan datang.

Gagasan EBT dilandasi pada Penggunaan energi hijau yang ramah lingkungan yang telah menjadi tuntutan Makhluk Hidup di planet bumi ini. Indonesia yang juga telah menyatakan komitmennya untuk terus memajukan dan meningkatkan Pemanfaatan Energi Baru dan Terbarukan sebagai bagian dari Paris Agreement dan sebagai Wujud keseriusan Indonesia terhadap Sustainable Development Goals (SDGs). Pada khususnya terletak pada poin SDGs No.7, yaitu memastikan akses energi yang terjangkau, andal, berkelanjutan, dan modern bagi semua. Gagasan Pemanfaatan EBT di Indonesia inipun sejalan dengan program Nawacita yang digagas oleh Presiden Joko Widodo. Sebagai implementasi SDGs tersebut, Kementerian Energi dan Sumber Daya Mineral (ESDM) kemudian menerjemahkannya menjadi 'Energi Berkeadilan yang Bertujuan Menyediakan Energi yang Berkelanjutan dan Terjangkau bagi Masyarakat. Sebagai perwujudan dan komitmen terhadap energi yang berkelanjutan, pemerintah telah melahirkan Blueprint kebijakan energi nasional, Dalam Blueprint cukup jelas menyebutkan jadwal dan besaran persentase yang harus dicapai adalah pada tahun 2025. Peran Energi Baru dan Terbarukan di Indonesia diharapkan sudah bisa mencapai 23-25\%. Kemudian target tersebut naik lagi menjadi 36\% pada 2050.

Energi Baru dan Terbarukan merupakan sumber daya alam yang Pemanfaatannya saat ini sangat dibutuhkan untuk menunjang kebutuhan hidup makhluk hidup terutama manusia. EBT memiliki peran sebagai Sumber daya alternatif yang dapat menggantikan Energi fosil yang sifatnya tidak dapat diperbaharui dan jumlahnya terbatas apabila digunakan secara terus-menerus. EBT pun dapat menjadi sebuah energi yang dapat dimanfaatkan secara berkelanjutan (Sustainable Energy) hingga masa yang akan datang. Pengaturan mengenai Energi alternatif EBT di Indonesia sendiri tercantum di dalam beberapa ketentuan peraturan perundang-undangan seperti pada Permen ESDM dan UU tentang Energi. Penetapan EBT dalam sebuah pengaturan hukum dimaksudkan agar setiap kebijakan mengenai EBT dapat terlaksana dengan E-ISSN: 2657-0300 Lembaga Penelitian dan Penerbitan Hasil Penelitian Ensiklopedia 23 
baik dalam menghasilkan dan menciptakan Energi yang berkelanjutan dan berbasis ramah lingkungan sesuai dengan komitmen Negara Indonesia di dalam Perjanjian Paris untuk dapat memberikan jaminan terhadap ketahanan energi hingga masa yang akan datang dan mengurangi penggunaan Energi fosil yang dapat mengancam dan merusak lingkungan.

\section{Penutup}

Berdasarkan penyajian diatas maka penelitian ini akan memberikan masukan terhadap urgensi pengaturan pengembangan energi terbarukan sebagai wujud mendukung ketahanan energi nasional, mengingat permasalahan yang dihadapi Indonesia seperti: produksi minyak bumi terus menurun, rasio penemuan cadangan/produksi rendah, ketergantungan impor energi membesar, proposi batubara yang diekspor terlalu besar, besarnya proposi ekspor LNG dan gas bumi serta masih lamanya keterikatan pada kontrak-kontrak ekspor jangka panjang. Urgensi pengaturan pengembangan energi terbarukan sebagai wujud mendukung ketahanan energi nasional, mengingat energi memiliki peranan yang sangat penting artinya bagi peningkatan kegiatan ekonomi dan keamanan nasional, sehingga pengelolaan energi yang meliputi penyediaan, pemanfaatan, dan pengusahananya harus dilaksanakan secara berkeadilan, berkelanjutan, optimal, dan terpadu. Serta mengingat bahwa cadangan sumber daya energi tak terbarukan terbatas, maka perlu adanya kegiatan penganekaragaman sumber daya energi agar ketersediaan energi terjamin.

\section{Datar Pustaka}

Beni Ahmad Saebani, Metode Penelitian Hukum, Pustaka Setia, Bandung, 2009.

C.F.G Sunaryati Hartono, Penelitian Hukum Di Indonesia Pada Akhir Abad Ke-20, Cetakan Kedua, Alumni, Bandung, 2006.

Farah Nabila, Menjaga Kedaulatan Energi Dengan Reformasi Kebijakan Diversifikasi Sumber Daya Energi, Jurnal Hukum dan Pembangunan, Tahun 45, Nomor 1, 2015.

Fery Triatmojo, Dinamika Kebijakan Diversifikasi Energi Di Indonesia: Analisis Kebijakan Pengembangan Energi Terbarukan Di Indonesia, Jurnal Ilmiah Administrasi Publik dan Pembangunan, Volume 4, Nomor 2, 2013.

Iwan J. Azis, et. al., Pembangunan Berkelanjutan dan Kontribusi Emil Salim, Kepustakaan Populer Gramedia, Jakarta, 2010.

Metta Dharmasaputra, Ancaman Krisis Minyak Bagi Pemerintah Baru, KataData, Jakarta, 2014.

Satya Widya Yudha, Paparan Wakil Ketua Komisi VII DPR RI, dalam acara Diskusi Nasional Kebijakan Energi, Universitas Gadjah Madah, Tanggal 16 April 2017.

Stephan S. Carey, A Beginner's Guide to Scientific Method, Wasworth Cengage Learning, 2004. (Penerjemah) Irfan M Zakkie, Kaidah-Kaidah Metode Ilmiah Panduan Untuk Penelitian dan Crtical Thinking, Nusamedia, Bandung, 2015. 